\title{
Генерація активних форм кисню в еритроцитах пацієнтів із політравмою та станом відміни алкоголю, ускладненим алкогольним делірієм
}

\section{А.В. Омельченко-Селюкова}

Харківський національний медичний університет, Харків, Україна

Анотація. Протягом останніх двох десятиліть відмічається глобальне зростання зловживання алкоголем і частоти розладів, пов'язаних з цим. Алкоголь $\epsilon$ провідним фактором ризику багатьох видів травм. Симптоми стану відміни алкоголю (СВА) виникають у 31\% пацієнтів із травмами. У пацієнтів із політравмою та СВА, ускладненим алкогольним делірієм, відмічають запальний процес, однією з відповідей організму на цей патологічний стан $є$ утворення активних форм кисню (АФК) нейтрофілами. Мета: визначити генерацію АФК в крові пацієнтів із політравмою та СВА з алкогольним делірієм залежно від способу седації. Об'єкт і методи дослідження. Обстежено 80 пацієнтів із політравмою середньої тяжкості та СВА, ускладненим алкогольним делірієм. Медіана віку становила 45 років. Пацієнтам 1-ї групи $(n=40)$ в якості методу седації обрано дексмедетомідин, у 2-й групі $(n=40)$ використовували седацію діазепамом за симптом-тригерним протоколом. Для діагностики делірію використовували метод оцінки сплутаності свідомості у пацієнтів, які перебувають у відділенні інтенсивної терапії (Confusion Assessment Method-Intensive Care Unit — CAM-ICU). Bизначення АФК в еритроцитах проводили методом проточної цитометрії із застосуванням програмного забезпечення «BD FACSDiva ${ }^{\mathrm{TM}}$ » («Becton Dickinson», США). Результати. У пацієнтів із політравмою та СВА, ускладненим алкогольним делірієм, виявлено значно підвищену генерацію АФК в еритроцитах, що зумовлює ериптоз. Висновок. Застосування дексмедетомідину може бути рекомендоване в якості седативного засобу в терапії алкогольного делірію у пацієнтів із політравмою та СВА.

Ключові слова: політравма, стан відміни алкоголю, алкогольний делірій, дексмедетомідин, активні форми кисню.

\section{Вступ}

Згідно з даними за 2018 р. в усьому світі 44\% чоловіків і 32\% жінок віком >15 років вживали надмірну кількість алкоголю [1]. Алкоголь виступає провідним фактором ризику для багатьох видів травм, потенціює агресивну поведінку та здатен подовжувати час реакції $[2,3]$. Кожного дня в результаті травматичних ушкоджень гинуть >16 тис. осіб, на кожного загиблого припадає кілька тисяч інвалідизованих, у багатьох з яких наслідки травми зберігаються протягом усього життя. 25-85\% пацієнтів перебувають у стані алкогольної інтоксикації під час госпіталізації до відділення травми та політравми [4]. Також відомо, що близько 16-26\% госпіталізованих мають проблеми, пов'язані із вживанням алкоголю. Симптоми стану відміни алкоголю (СВА) відмічають у $31 \%$ пацієнтів з травмами і у 16\% хворих хірургічного профілю в післяопераційний період [5]. Симптоми СВА виникають в середньому через 6-48 год після останнього вживання алкоголю та проявляються від помірних (головний біль, нудота, пітливість, тремор, тривога, безсоння) до тяжких (психомоторне збудження, галюцинації, алкогольний делірій, судоми). За даними різних авторів, 20-35\% пацієнтів зі СВА потребують госпіталізації у відділення інтенсивної терапії [2-4].

У свою чергу, у хворих із політравмою та СВА, ускладненим алкогольним делірієм, виявляють запальний процес. Однією з відповідей організму на цей патологічний стан $€$ утворення активних форм кисню (АФК) нейтрофілами. Надмірна продукція АФК впливає на стан клітинних мембран, порушує їх фізико-хімічні властивості та руйнує клітини, викликає окисну модифікацію білків.

На даний час в науковій літературі не знайдено жодних повідомлень щодо визначення АФК в еритроцитах пацієнтів із політравмою та СВА, ускладненим алкогольним делірієм. Тому доцільно визначити генерацію АФК, що $€$ тригером розвитку ериптозу.

Мета: визначити генерацію АФК в крові пацієнтів із поєднаною травмою та СВА з алкогольним делірієм залежно від способу седації.

\section{Об'єкт і методи дослідження}

у дослідженні взяли участь 80 пацієнтів із політравмою середньої тяжкості та СВА, ускладненим алкогольним делірі$\epsilon \mathrm{M}$, які перебували на лікуванні у період 2016-2017 рр. на базі відділення політравми та анестезіології на 12 ліжок для інтенсивної терапії хворих зі сполученою травмою комунального некомерційного підприємства «Міська клінічна лікарня швидкої та невідкладної медичної допомоги ім. проф. О.І. Мещанінова» Харківської міської ради. У контрольну групу включили 20 здорових добровольців віком 20-48 років.

Критерії включення у дослідження:

- вік 19-60 років;

- наявність пошкоджень у $\geq 2$ анатомо-функціональних ділянках;

- ступінь тяжкості травматичного пошкодження за шкалою оцінки тяжкості пошкодження (Injury Severity Score - ISS) 9-15 балів (середня тяжкість);

- тяжкість стану постраждалих за шкалою оцінки гострих фізіологічних змін та хронічного стану здоров'я (Acute Physiology And Chronic Health Evaluation - APACHE) II 7-14 балів;

- стан хронічної алкогольної інтоксикації, виявлений при кількості балів $\geq 7$ у модифікованому тесті «Сітка LeGo»;

- $\geq 3$ позитивних відповідей в опитувальнику CAGE (Cut down, Annoyance, Guilty, Eye-opener);

- встановлений алкогольний делірій - збудження за шкалою збудження-седації Річмонда (Richmond Agitation-Sedation Scale - RASS) $\geq+2$;

- галюцинації;

- судоми;

- наявність делірію за методом оцінки сплутаності свідомості у пацієнтів, які перебувають у відділенні інтенсивної терапії (BIT) (Confusion Assessment Method-Intensive Care Unit CAM-ICU).

Усім 80 хворим в стаціонарі проводили обстеження згідно 3 медико-економічними стандартами надання медичної допомоги. Під час проведення дослідження систематично використовували принципи Гельсінської декларації Всесвітньої медичної асоціації «Етичні принципи медичних досліджень за участю людини у якості об'єкта дослідження». Письмова інформована згода отримана в усіх хворих, які брали участь у дослідженні.

3 урахуванням методів седації пацієнтів розподілено на дві групи, що дозволяло забезпечити реалізацію завдань дослідження. Для розподілу пацієнтів використовували фіксовану просту рандомізацію із застосуванням методу випадкових чисел.

1-ша група ( $\mathrm{n}=40)$ включала пацієнтів із політравмою та тяжким СВА, ускладненим алкогольним делірієм, яким проводи- 
ли седацію дексмедетомідином. Початкову швидкість інфузії встановлювали на рівні 0,7 мкг/кг/год та коригували в межах 0,2-1,4 мкг/кг/год залежно від досягнення цілей седації (від -2 до 0 за шкалою RASS) і оцінки за шкалою CIWA-Ar (Clinical Institute Withdrawal Assessment of Alcohol Scale) $<15$.

2-га група ( $\mathrm{n}=40)$ включала пацієнтів із політравмою та тяжким СВА, ускладненим алкогольним делірієм, яким проводили седацію діазепамом за симптом-тригерним протоколом. Діазепам вводили кожні 30 хв у міру необхідності, щоб контролювати активні симптоми відміни.

Визначення АФК В еритроцитах проводили методом проточної цитометрії 3 використанням барвника 2',7'-дихлордигідрофлуоресцеїну діацетату (H DCFDA). Аліквоти свіжої цільної крові від пацієнтів та здорових людей були зібрані в вакутейнери з $\mathrm{K}_{2}$ етилендіамінтетраоцтовою кислотою (ЕДТА). Проби відмивали розчином Рінгера. Після розщеплення естеразою та подальшого окиснення АФК нефлуоресцуючий барвник $\mathrm{H}_{2}$ DCFDA утворює флуоресцентний продукт 2,7'-дихлорфлуоресцеїн (DCF). Для аналізу середньої інтенсивності флуоресценції DCF в еритроцитах використовували програмне забезпечення «BD FACSDiva ${ }^{\mathrm{TM}}$ » («Becton Dickinson», США) [6].

\section{Результати}

Визначено, що у здорових осіб генерація АФК в еритроцитах становила $39 \pm 3,2$ у.о. (рис. 1).

Рисунок 1 Генерація АФК в еритроцитах практично здорової особи, інтенсивність флуоресценції DCF в еритроцитах

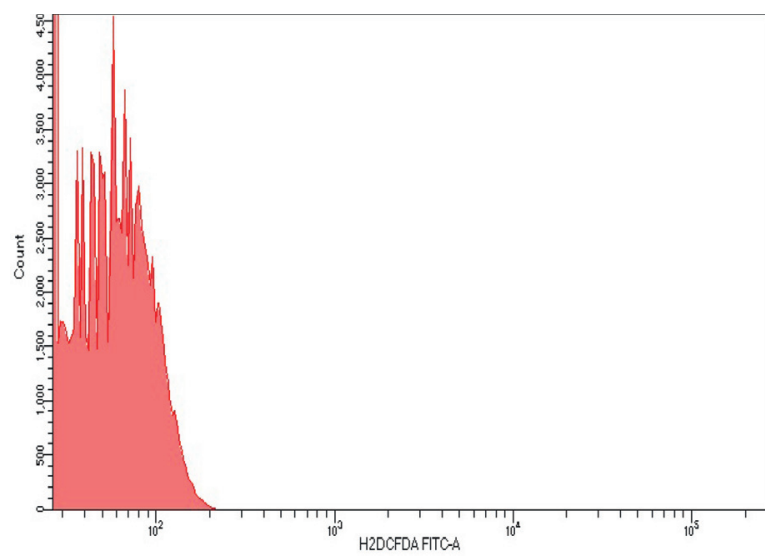

У пацієнтів 1-ї групи під час надходження до ВІT генерація АФК в еритроцитах становила $182 \pm 19,6$ у.о., що в 4,67 раза більше, ніж у здорових осіб (рис. 2).

Рисунок 2 Генерація АФК в еритроцитах хворого 1-ї групи з політравмою та СВА, ускладненим алкогольним делірієм, під час надходження до стаціонару, інтенсивність флуоресценції DCF в еритроцитах (у.о.)

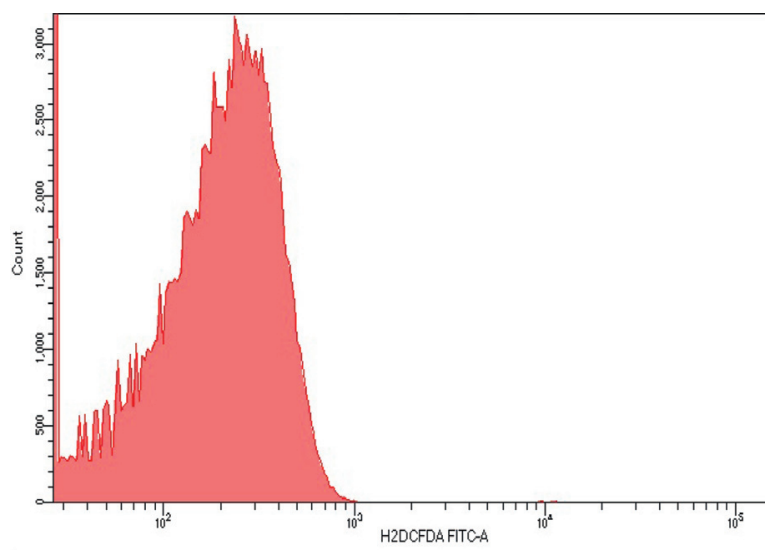

Після проведеної інтенсивної терапії із застосуванням дексмедетомідину через 1 тиж відмічали значне зниження генерації
АФК в еритроцитах, а саме в 1,56 раза, яке, однак, не досягало рівня у контрольній групі (рис. 3).

Рисунок 3 Генерація АФК в еритроцитах хворого 1-ї групи на 7-му добу лікування, інтенсивність флуоресценції DCF в еритроцитах (у.о.)

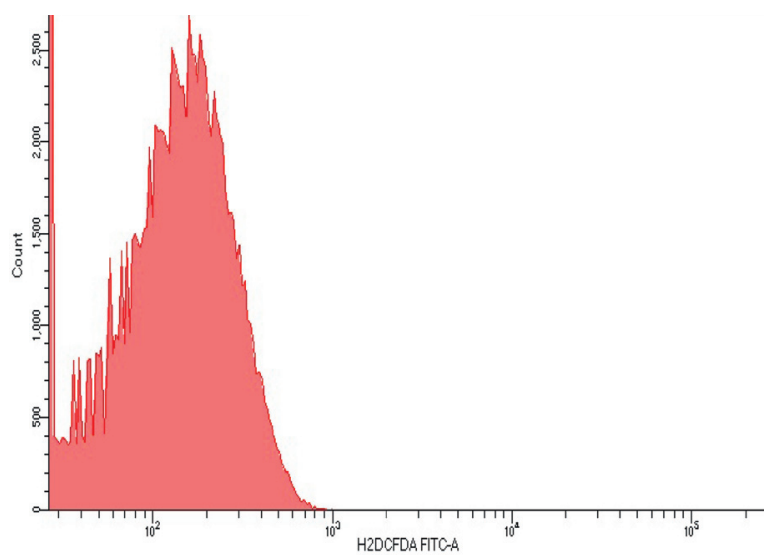

Схожий характер змін генерації АФК відмічали й у хворих 2-ї групи. Під час надходження до ВІТ генерація АФК в еритроцитах становила $154 \pm 13,8$ у.о. (рис. 4).

Рисунок 4 Генерація АФК в еритроцитах хворої 2-ї групи під час надходження до BIT, інтенсивність флуоресценції DCF в еритроцитах (у.о.)

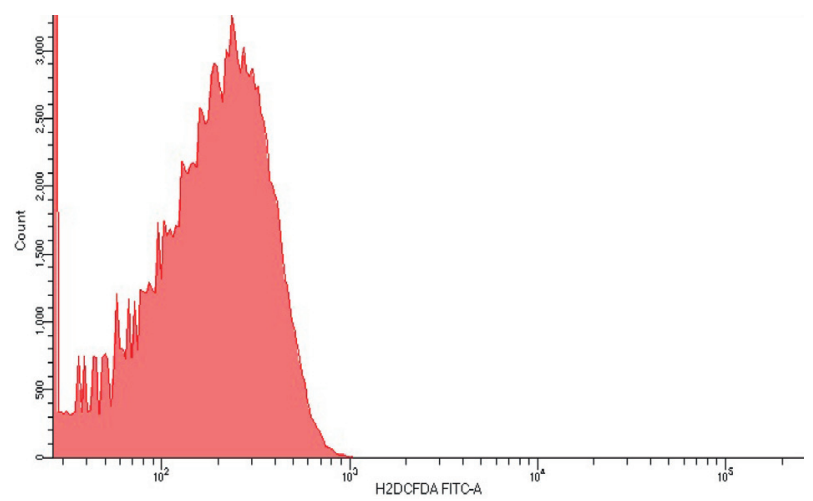

Після проведеної інтенсивної терапії у хворих 2-ї групи незначно знижувалася генерація АФК, а саме на $15,6 \%$, та залишалася на 33,35\% вище відповідного показника у контрольній групі (рис. 5).

Рисунок 5 Генерація АФК в еритроцитах хворого 2-ї групи на 7-му добу лікування, інтенсивність флуоресценції DCF в еритроцитах (у.о.)

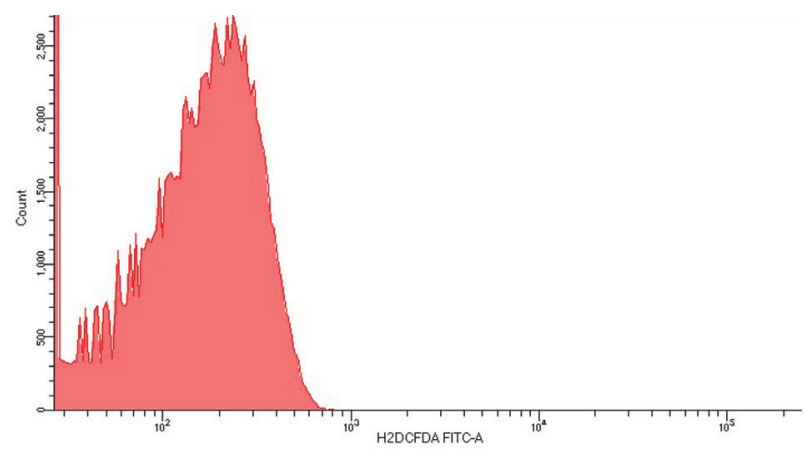

\section{Обговорення}

Під час циркуляції в крові еритроцити піддаються дії оксидативного стресу. У фізіологічних умовах існують антиоксиданти, які підтримують оксидантно-антиоксидантний баланс. Зниження активності компонентів антиоксидантної ферментативної системи, зокрема супероксиддисмутази, каталази, глутатіонпе- 
роксидази, що відмічається у цих пацієнтів [7], викликає імбаланс окисно-відновлювального потенціалу еритроцитів та трансформацію фосфоліпідів клітинної мембрани еритроцитів.

За своєю суттю підвищення АФК в еритроцитах призводить до ериптозу - процесу, що нагадує апоптоз ядровмісних клітин. Цей процес відбувається шляхом зморщування клітин, переміщення молекул фосфоліпідів з одного боку цитоплазматичної мембрани в інший, що призводить до зміни властивостей та функціональної активності еритроцитів [8]. Скремблювання фосфоліпідів клітинних мембран еритроцитів під час ериптозу зумовлює транслокацію фосфатидилсерину на зовнішній бік цитоплазматичної мембрани. Поява фосфатидилсерину в зовнішньому шарі мембрани викликає активацію макрофагів. Визначено, що запуском ериптозу $\epsilon$ підвищення внутрішньоклітинної концентрації вільних іонів кальцію, а також дія ксенобіотиків [9].

\section{Висновок}

У хворих з політравмою та СВА, ускладненим алкогольним делірієм, відмічали значну підвищену генерацію АФК в еритроцитах, що зумовлює ериптоз та в подальшому буде призводити до розвитку анемії та поглиблення гіпоксичного стану. При застосуванні дексмедетомідину в якості седативного засобу в терапії алкогольного делірію у пацієнтів із політравмою та СВА виявлено значне зниження генерації АФК через 7 діб лікування

\section{Конфлікт інтересів}

Автор заявляє про відсутність конфлікту інтересів і власної фінансової зацікавленості при підготовці цієї статті.

\section{Інформація про фінансування}

Дослідження виконувалося як частина науково-дослідницької роботи кафедри медицини невідкладних станів, анестезіології та інтенсивної терапії Харківського національного медичного університету МОЗ України «Вибір методів знеболення та інтенсивної терапії у пацієнтів із синдромом системної запальної відповіді» (№ державної реєстрації 0199U001773).

\section{Перспективи подальших досліджень}

Дослідження будуть продовжені у напрямку вивчення впливу седації дексмедетомідином на стадії клітинної загибелі лейкоцитів у пацієнтів із поєднаною травмою та СВА.

\section{Список використаної літератури}

1. World Health Organization (2019) Global status report on alcohol and health 2018.

2. Riuttanen A., Jäntti S.J., Mattila V.M. (2020) Alcohol use in severely injured trauma patients, Sci. Rep., 10(1): 17891. doi: 10.1038/s41598-020-74753-y.

3. Guinle M.I.B., Sinha R. (2020) The Role of Stress, Trauma, and Negative Affect in Alcohol Misuse and Alcohol Use Disorder in Women. Alcohol Res., 40(2): 5. doi: 10.35946/arcr.v40.2.05.

4. Mainerova B., Prasko J., Latalova K. et al. (2015) Alcohol withdrawal delirium — diagnosis, course and treatment. Biomed. Pap. Med. Fac. Univ. Palacky Olomouc. Czech Repub., 159(1): 44-52. doi: 10.5507/bp.2013.089.

\section{Відомості про автора:}

0мельченко-Селюкова Анна Валеріївна — аспірант кафедри медицини невідкладних станів, анестезіології та інтенсивної терапії, Харківський національний медичний університет, Харків, Україна. ORCID: 0000-0001-5965-8526

Адреса для кореспонденції:

Омельченко-Селюкова Анна Валеріївна

61022, Харків, просп. Науки, 4

E-mail: anna.omelcenkokh@gmail.com
5. ASAM (2020) The ASAM Clinical Practice Guideline on Alcohol Withdrawal Management. J. Addict.Med., 14(3S Suppl. 1): 1-72. doi: 10.1097/ADM.0000000000000668.

6. Onishchenko A., Myasoedov V., Yefimova S. et al. (2021) UV Light-Activated GdYVO ${ }_{4} \mathrm{Eu}^{3+}$ Nanoparticles Induce Reactive Oxygen Species Generation in Leukocytes Without Affecting Erythrocytes In Vitro. Biol. Trace Elem. Res. doi: 10.1007/s12011-021-02867-z.

7. Omelchenko-Seliukova A. (2021) The dynamic of indicators of lipid peroxidation and antioxidant protection status in patients with polytrauma and alcohol withdrawal syndrome complicated by alcohol delirium. World Sci., 11(72) https://doi.org/10.31435/rsglobal_ ws/30122021/7729.

8. Vaschenko V.I.,Vil'yaninovV.N. (2019) Eryptosis (quasi-apoptosis) the human red blood cells. Its role in medicinal therapy. Rev. Clin. Pharmacol. Drug Ther., 17(3): 5-38. doi: 10.17816/ RCF1735-38.

9. Tkachenko A., Kot Y., Prokopyuk V. et al. (2021) Food additive E407a stimulates eryptosis in a dose-dependent manner. Wien Med. Wochenschr. doi: 10.1007/s10354-021-00874-2.

\section{Generation of reactive oxygen species in erythrocytes in patients with polytrauma and alcohol withdrawal complicated by alcoholic delirium}

\section{A.V. Omelchenko-Seliukova}

Kharkiv National Medical University, Kharkiv, Ukraine

Abstract. The last two decades have seen a global increase in alcohol abuse and the incidence of alcohol-related disorders. In turn, alcohol is a leading risk factor for many types of injuries. Alcohol withdrawal symptoms (AWS) occur in 31\% of trauma patients. In patients with polytrauma and AWS, complicated by alcoholic delirium, there is an inflammatory process, one of the body's responses to this pathological condition is the formation of reactive oxygen species (ROS) by neutrophils. Aim: to determine the generation of ROS in the blood in patients with polytrauma and AWS with alcoholic delirium, depending on the method of sedation. Materials and methods of the research. Eighty patients with moderate polytrauma and AWS complicated by alcoholic delirium were examined. The median age was 45 years. In patients of Group $1(n=40)$ dexmedetomidine was chosen as the method of sedation, in Group $2(n=40)$ sedation with diazepam according to the symptom-trigger protocol was used. The Confusion Assessment Method-Intensive Care Unit (CAM-ICU) method was used to diagnose delirium. Determination of ROS in erythrocytes was performed by flow cytometry using «BD FACSDiva ${ }^{\mathrm{TM}}$ » software ("Becton Dickinson", USA). Results. In patients with polytrauma and AWS, complicated by alcoholic delirium significantly increased generation of ROS in erythrocytes was found, which promotes eryptosis. Conclusion. The use of dexmedetomidine may be recommended as a sedative in the treatment of alcoholic delirium in patients with polytrauma and AWS.

Key words: polytrauma, alcohol withdrawal syndrome, alcoholic delirium, dexmedetomidine, reactive oxygen species.

\section{Information about the author:}

Omelchenko-Seliukova Anna V. — postgraduate student of the Department of Emergency Medicine, Anesthesiology and Intensive Care, Kharkiv National Medical University, Kharkiv, Ukraine. ORCID: 0000-0001-5965-8526

Address for correspondence:

Anna Omelchenko-Seliukova

61022, Kharkiv, Nauki ave., 4

E-mail: anna.omelcenkokh@gmail.com 